\title{
HEINONLINE
}

Citation: 47 J. Church \& St. 1332005

Content downloaded/printed from

HeinOnline (http://heinonline.org)

Thu Feb 24 08:22:38 2011

-- Your use of this HeinOnline PDF indicates your acceptance of HeinOnline's Terms and Conditions of the license agreement available at http://heinonline.org/HOL/License

-- The search text of this PDF is generated from uncorrected OCR text.

-- To obtain permission to use this article beyond the scope of your HeinOnline license, please use:

https://www.copyright.com/ccc/basicSearch.do?

\&operation $=$ go\&search Type $=0$

\&lastSearch $=$ simple\&all=on\&titleOrStdNo=0021-969X 


\title{
School and Religion in Spain
}

\author{
JAVIER MARTÍNEZ-TORRÓN
}

\section{A. The CONSTITUTIONAL CONTEXT}

\section{Religion in the Spanish Constitution}

The current legal and political framework of religion in Spain was designed by the Spanish Constitution and enacted on 27 December 1978 (three years after General Franco died and Spain's political transition to democracy began), which transformed the prior regime into a democratic state that meets the standards of freedom characteristic of Western democracies. This is the first Spanish Constitution that has provided an adequate solution to the social and political conflicts that religious ideas have traditionally caused in Spain. The reason for this success is that the Constitution of 1978 effected a gradual transformation of the Spanish confessional state into a regime based on religious freedom without breaking abruptly with the nation's historical tradition.

In the following years, the Spanish state signed the most relevant international documents regarding human rights, including the European Convention of Human Rights. Spanish society, in its largest part, accepted rapidly and deeply the new model of political life, which was in overt contrast with General Franco's dictatorship (Franco ruled the country from the end of Spain's civil war in 1939 until his death in 1975). In the last twenty-five years, religious pluralism has notably increased, and is no longer seen by Spaniards as a negative reality or as contrary to the Spanish traditional identity, but

\footnotetext{
-JAVIER MARTÍNEZ-TORRÓN (J.D., University of Granada; J.C.L., J.C.D., University of Navarra; Professor of Law, University of Granada) is professor of law, Complutense University of Madrid. He has contributed to several volumes, including Facilitating Freedom of Religion and Belief: A Deskbook; Global Jurist Advances; Religions of the World: A Comprehensive Encyclopedia of Beliefs and Practices; and Religious Liberty and Human Rights, among others. His articles have appeared in Brigham University Law Review, Revista Española de Derecho Constitucional, Helsinki Monitor, Review Générale de Droit, and Il Diritto Eclesiástico, among others. Special interests include freedom of religion or belief in the European Convention of Human Rights, church-state relations, and integration of Islamic minorities in Western democracies. The text reproduces, with slight modifications, the National Report to the $15^{\text {th }}$ Conference of the European Group of Public Law ("Religion and Public Law"), Athens, Greece, 16-18 September 2004.
} 
rather as the normal effect of freedom. Religion has ceased to be, for the first time in many centuries, a source of social and political conflict.

Spain was a confessional state from the time that it became a unified kingdom in the late fifteenth century; the state officially professed Catholicism, and there existed an inseparable nexus between Catholicism and Spain's national identity. ${ }^{1}$ The state's public endorsement of the Catholic faith was usually accompanied by intolerance of other religions with an intensity that varied according to the political and religious circumstances. For almost five hundred years, the Catholic confessionality of the Spanish state experienced only two ephemeral interruptions: the Constitution of 1869 (derogated in 1876), and the Republican Constitution of 1931.2 Indeed, the gravest mistake of the Constitution of 1931-Spain's last democratic Constitution prior to 1978-was its hostile attitude toward the Catholic Church. The Republican Constitution proclaimed the general principle of freedom of religion and conscience, but in an attempt to diminish the Catholic Church's extensive influence on the country's national political and cultural life, it imposed severe restrictions on the actual freedom of ecclesiastical institutions. ${ }^{3}$ These restrictive provisions, together with their development by

1. It is usually assumed that the Spanish kingdom began in 1492 when Queen Isabel of Castille and King Ferdinand of Aragon, who married in 1469, conquered the Moorish kingdom of Granada. Significantly, Ferdinand and Isabel are known as the "Catholic Kings" ("Reyes Católicos"), because the spreading and strengthening of Catholicism allegedly formed one of their main goals in politics, within the territory of the Spanish peninsula as well as in the subsequent colonization of America. Ferdinand and Isabel's two most dramatic decisions involving religious issues involved the expulsion of Jews and Muslims in 1492 and 1502, respectively. The faithful of these two religions had to either convert to Catholicism, the "true religion," or leave the kingdom. This religious policy was continued by succeeding kings. Philip the Second, for instance, promulgated in 1564, as "laws of the kingdom," the decrees of the Council of Trent, historically known as the CounterReformation Council. Even the Constitution that introduced the spirit and doctrines of liberalism into Spain, the 1812 Constitution of Cádiz, began with an invocation to "Almighty God, Father, Son and Holy Spirit" (author's translation), and enshrined the Catholic religion as part of the political structure of the Spanish state with the following words: "The religion of the Spanish Nation is, and will perpetually be, the Catholic, Apostolic, Roman religion, which is the only true one. The Nation protects it by wise and just laws, and prohibits the exercise of any other religion." (art. 12, author's translation). For a succinct and interesting synopsis of the history of church-state relationships in Spain during the last three centuries, with abundant bibliographical references, see P. Lombardia, "Precedentes del derecho eclesiástico español," in the collective volume Derecho eclesiástico del Estado español, 2nd ed. (Pamplona, Spain, 1983), 111. See also J. Martínez-Torrón, entry [Religion in] Spain, in Religions of the World: A Comprehensive Encyclopedia of Beliefs and Practices, 4 vols., eds. J. G. Melton and M. Baumann (Santa Barbara, Calif., 2002). For a more detailed study, with regard to the nimeteenth and twentieth centuries, see J. M. Cuenca Toribio, Relaciones Iglesia-Estado en la España contemporánea: 1833-1985 (Madrid, 1985).

2. The Constitution of 1869 , art. 21 , recognized the state's obligation to support the Catholic Church without establishing Catholicism as the state religion. Art. 3 of the Constitution of 1931 provided that "The Spanish state has no official religion" (author's translation).

3. Art. 27 provided: "Freedom of conscience and the right to freely profess and practice 
statutory law and the strongly anti-clerical attitude of some of the Republican governments, largely provoked the social and political convulsions that ended tragically in the Spanish Civil War (1936-1939) and led to General Franco's dictatorship (1939-1975). 4

As previously indicated, the Constitution of 1978 renounced Catholic confessionality and explicitly declared that the Spanish state has no official religion. ${ }^{5}$ More precisely, the constitutional framework of religion is based upon four fundamental principles: religious freedom, equality, neutrality, and cooperation. 6 The state protects the exercise of freedom of religion and

any religion are guaranteed within the Spanish territory, with the exceptions derived from the due respect to public morals" (author's translation). However, the same article subjected all cemeteries to the state's authority and interdicted the establishment of separate religious sections within state cemeteries; only private worship was permitted (public acts of worship were subject to a specific authorization by government). In any event, the very heart of the problem was art. 26. According to the different provisions of this article, all financial aid to the Catholic Church was suppressed, including tax benefits for religious corporations (it should be noted that the state's economic support was a sort of compensation for the massive confiscation of ecclesiastical property in the nineteenth century). All religions were considered as "associations subjected to a special law." The Order of Jesuits was dissolved, and other religious orders and congregations were subjected to different legal controls and restrictions, in particular with regard to their capacity to acquire and administer property. In addition, they were prohibited from engaging in teaching activities; this provision was particularly severe and certainly unrealistic, considering that most schools in Spain were in the hands of the church.

4. On the religious policy of the Second Republic, see generally J. Martínez-Torrón, "Derecho de asociación y confesiones religiosas en la Constitución de 1931," in Cuestiones Constitucionales (México) 3 (2000): 91, and the bibliography cited therein. For an analysis of the religious policy of General Franco's regime, see A. De La Hera, "Las relaciones entre la Iglesia y el Estado en España (1953-1974)," Revista de Estudios Políticos 5 (1977): 211.

5. The Constitution primarily deals with religion in articles 16 (freedom of ideology, religion and worship) and 14 (principle of equality). Article 16 states:

a. Freedom of ideology, religion and worship of individual and communities is guaranteed, with no other restriction on their expression than may be necessary to maintain public order as protected by law.

b. Nobody may be compelled to make statements regarding his religion, beliefs or ideology.

c. There shall be no state religion. The public authorities shall take the religious beliefs of Spanish society into account and shall in consequence maintain appropriate relationships of cooperation with the Catholic Church and the other religious denominations.

Similarly, article 14 provides that "Spaniards are equal before the law and may not in any way be discriminated against on account of birth, race, sex, religion, opinion or any other condition or personal or social circumstance" (both articles translated in Spanish Legislation on Religious Affairs, eds. A. de la Hera and R. M. Martínez de Codes, (1998), 25, 39-40). Other provisions of the Constitution that directly or indirectly relate to freedom of religion and belief include article 30 (conscientious objection to military service), article 27 (right to education and freedom of teaching), article 20 (freedom of expression), and article 22 (freedom of association).

6. See G. Morán, "The Spanish System of Church and State," in Brigham Young University Law Review 2 (1995): 535; J. Ferrer Ortiz, "Los principios informadores del 
conscience by every individual and group. All citizens are equal before the law and therefore no one can be subjected to discrimination on the basis of religion or beliefs. Neutrality determines that the state has no official religion and may not evaluate the different religious groups according to their doctrines or tenets; it may only judge their social effects. Neutrality, in turn, is understood according to the principle of state cooperation with religion. Thus, state neutrality can not be understood as imposing a strict separation between state and religion, or a sort of French-style "secular confessionality" (laïcité).7 Freedom of religion and belief, as well as cooperation with churches, defines state policy on religious affairs.

The constitutional right to religious freedom was developed by a statute enacted in 1980: the Organic Law on Religious Freedom, 8 which deals both with the individual aspects of religious freedom and with the main issues regarding the relationships between the state and religious denominations.

\section{The Specific Mention of the Catholic Church in the Constitution}

The major church in Spain is, by far, the Catholic Church. ${ }^{9}$ The only

derecho eclesiástico del Estado," in La libertad religiosa y de conciencia ante la justicia constitucional, (Granada, 1998), 107. For the case law of the Constitutional Court on those principles, see J. Calvo Alvarez, Los principios del Derecho eclesiástico español en las sentencias del Tribunal Constitucional (Pamplona, 1998); J. Martínez-Torron "Freedom of Religion in the Case-Law of the Spanish Constitutional Court," in Brigham Young University Law Review 2 (2001): 711.

7. On this subject, see generally M.J. Roca, "La neutralidad del Estado: fundamento doctrinal y delimitación en la jurisprudencia," in Il diritto ecclesiastico (1997), 1: 405. See also J. Martínez-Torrón, Religión, derecho y sociedad (Granada, 1999), 172.

8. Ley Orgánica $7 / 1980$, de Libertad Religiosa, 5 July 1980 . The process of elaboration of this law has been studied by M.J. Ciaurriz, La libertad religiosa en el derecho español. La Ley Orgánica de Libertad Religiosa (Madrid, 1984), 31-91.

9. From a sociological perspective, it is very difficult to find reliable statistics, especially with regard to the degree of religious practice or of regular attendance to worship ceremonies. However, it is undisputed that the Catholic Church is the religion of the overwhelming majority of Spain's population. Over a population of 40 million, approximately 90 percent of Spaniards recognize themselves as Catholics, while less than 2 percent believe in other religions, and 8 percent declare not to have any religion (these data correspond to 1990-1996, and the percentage experienced only minimal variations in those years); 75 percent of marriages are celebrated according to canon law; parents demand Catholic instruction in schools-public and private-for approximately 80 percent of high school students. The Spanish cities of Ceuta and Melilla, located in the coast of Northern Africa, constitute an exception; in these enclaves Muslims may reach 25 percent and 35 percent of the population, respectively. The number of Jews is probably not beyond 20,000 people. The Evangelical federation counts likely no more than 140,000 members; and the Islamic federation, approximately 350,000 (many of them are immigrants from Islamic countries). Jehovah's Witnesses are less than 100,000, and Mornons around 30,000.

The Catholic Church still retains a powerful social influence, although public morals are much less rooted in Catholic doctrine than in the recent past. Like in other European countries with a traditional majority church, there is an increasing trend in Spain-even among people who define themselves as Catholic-towards living openly in agreement with 
explicit mention of this church in the Spanish Constitution is found in article 16(3), which provides that "the public authorities shall take the beliefs of Spanish society into account and shall in consequence maintain appropriate relationships of cooperation with the Catholic Church and the other religious denominations."

After the Constitution was enacted, Spanish scholars widely discussed the possible legal effects of this specific mention of the Catholic Church. The passage of time has demonstrated that the mens legislatoris in that article did not seem to go beyond what could be described as a "tranquilizing effect." To explain it in brief, the new regime of relationships between the state and religion implied a deep change in Spanish tradition. The drafters of the Constitution did not want the Catholic hierarchy to think that they were following the example of the Constitution of 1931, in which-as indicated above- a sort of vendetta against ecclesiastical institutions replaced the Catholic confessionality of the state. Including the name of the Catholic Church in article 16(3) helped to avoid the risk of a negative reaction on the part of the most conservative religious circles in Spain, and contributed to the elimination of possible attacks against the extraordinary political change that was taking place in Spain, which some influent social forces of Catholic pedigree regarded with diffidence. This explains an apparent paradox: the support of the Communist Party - which traditionally had been, and was in 1978, an anticlerical party-for the reference of article 16(3) to the Catholic Church. 10

In January 1979, a few days after the Constitution was enacted, the Spanish state decided to continue the concordatarian tradition characteristic of Spain since the eighteenth century. The old concordat signed in 1953under Franco's regime-was replaced by a set of four agreements with the holy see, which, in fact, collectively constitute a concordat and are assimilated into international treaties in Spanish law. The purpose of these agreements was to preserve those traditional privileges of the Catholic Church that were deemed compatible with the new constitutional principles (e.g., civil effects of canonical marriage, religious education in public schools as an optional subject for students-but mandatory for the schools-financial support, religious assistance to the Army, etc.).

Thus, the cooperation with the Catholic Church materialized in a bilateral legal instrument aimed at guaranteeing a specific legal status to the major church in Spain. An interesting consequence is that, as a practical application of the equality principle, the 1980 Organic Law on Religious Freedom (art. 7)

ethical rules not entirely coincident with official Catholic morals, and towards a less close relationship with the ecclesiastical establishment. The number of clergymen and members of religious orders has been diminishing in the last decades (although it seems stable in the last years). At the same time, there is a growing number of charitable institutions and NGOs of Catholic inspiration, with numerous young volunteers.

10. For an analysis of the constitutional debates on Art. 16 in the Spanish Cortes Constituyentes, see J.J. Amorós, La libertad religiosa en la Constitución española de 1978 (Madrid, 1984), 120-53. 
opened the same possibility, for the first time in Spanish history, to other religious denominations that have acquired "well-known roots." In other words, the relationships of cooperation with the Catholic Church urged state cooperation with non-Catholic religions (which had been nonexistent before). Many advantages given in 1979 to the Catholic Church were subsequently granted also to some of the main religious minorities in Spain, in particular to those of more historical significance, when the Spanish state signed, in 1992, three agreements of cooperation with three federations of Evangelical churches, Jewish communities, and Islamic communities, respectively (i.e., the same religions that were persecuted by the Spanish monarchy five centuries ago).11 The content and literal text of the three agreements is very similar.

Although statutes and bylaws enacted after the Constitution have created different channels for state cooperation with churches, the main instruments of this cooperation are the aforementioned agreements with the Catholic Church and with Evangelical, Jewish, and Islamic communities. Still, the remaining religious groups are accorded the same freedom of ones that have an agreement with the state, and can easily acquire legal rights in Spanish law through a simple procedure of registration. In any event, most of the more than eight hundred non-Catholic religious communities registered in Spain are integrated into those federations. If we except Jehovah's Witnesses and Mormons, the cooperation agreements with the Catholic Church (1979) and with religious minorities (1992) are representative of a very high percentage of the Spanish population. For this reason, the present state of affairs is usually deemed satisfactory. Viewed in the context of Spanish history, the existing problems are relatively unimportant.

\section{The Spanish State and Education}

Art. 27 of the Spanish Constitution 12 assigns to the State the responsibility

11. The establishment of cooperative agreements between the state and non-Catholic religious denominations constituted an innovative addition to the Spanish legal tradition and was inspired by the Italian Constitution, which in turn was inspired by German law. In Spain, these agreements were created in abstracto by article 7 of the Organic Law of Religious Freedom, which allows the government to negotiate cooperative agreements with religious denominations of particular social significance and requires that such agreements be approved by a specific act of Parliament. The new institution was put into practice for the first time (and, presently, also for the last time) in 1992, when Parliament approved three agreements with the Evangelical churches, the Jewish communities, and the Islamic communities, all of which are very similar in content. In the following years, the Jehovah's Witnesses and the Mormon Church endeavored, without success, to reach an agreement with the state. For an analysis of the 1992 agreements in the context of Spanish constitutional principles and in light of comparative law, see generally J. Martínez-Torrón, Separatismo y cooperación en los acuerdos del Estado con las minorías religiosas (Granada, 1994); G. Morán, "The Legal Status of Religious Minorities in Spain," Joumal of Church and State 36 (1994): 577; and, more recently, D. García Pardo, El sistema de acuerdos con las confesiones minoritarias en España e Italia (Madrid, 1999).

12. This is the text of article 27 (author's translation): 
of guaranteeing the citizens' right to education and organizing the educational system. The right to education is conceived as a right of every citizen that, among other things, entitles (and obliges) the receiving of elementary education free of charge. The aim of education is understood as "the full development of human personality within respect for democratic principles and for fundamental rights and freedoms."

Although the educational system is ultimately the responsibility of the state, it does not mean that all teaching centers have to be owned or run by the state. On the contrary, as freedom of teaching is also recognized to all citizens, individuals as well as legal persons have the right to establish educational centers, with respect to the constitutional principles. Naturally, this right must be exercised within the legal framework designed by the state to guarantee the quality and efficiency of the educational system.

Article 27 includes an explicit reference to the role of religious and/or moral instruction in the youth's education. In accordance with the provisions of art. 2 of the First Protocol to the European Convention of Human Rights, 13 art. 27(3) of the Constitution recognizes the parents' right to ensure that their children shall receive in school religious and moral instruction according to their convictions or beliefs. This right was reiterated, in similar terms, by the 1985 Organic Law on the Right to Education, 14 and more recently in the 2002 Organic Law on the Quality of Education ${ }^{15}$ (which modifies some parts of the

a. Everybody has the right to education. Freedom of teaching is recognized.

b. Education shall have as its aim the full development of human personality, within respect for democratic principles and for fundamental rights and freedoms.

c. Public authorities guarantee the parents' right to ensure that their children receive moral and religious instruction in accordance with their own convictions.

d. Elementary education is compulsory and free.

e. Public authorities guarantee the right of everyone to education, through general planning of education, with the effective participation of all parties concerned and the setting up of teaching establishments.

f. The right of individuals and legal persons to set up educational centres is recognized, provided that they respect Constitutional principles.

g. Teacher, parents and, when appropriate, pupils, shall participate in the control and management of all the centres maintained by the Administration out of public funds, in the conditions to be specified by the law.

h. Public authorities shall inspect and standardize the educational system in order to guarantee compliance with the law.

i. Public authorities shall provide support to the educational centres that meet the requirements to be established by the law.

$\mathrm{j}$. The autonomy of Universities is recognized, under the conditions to be established by the law.

13. Art. 2 of the Protocol provides: "No person shall be denied the right to education. In the exercise of any functions which it assumes in relation to education and to teaching, the state shall respect the right of parents to ensure such education and teaching in conformity with their own religious and philosophical convictions."

14. Ley Orgánica 8/1985, del Derecho a la Educación, 3 July 1985, art. 4(c).

15. Ley Orgánica 10/2002, de Calidad de la Educación, 23 December 2002, art. 3(c). 
former).

Thus, confessional religious education in public schools is primarily understood as a right of the parents rather than as a right of the churches or religious communities (the adjective "confessional" is important, for, as we will see, the current system provides both for a confessional and non-confessional teaching of religion).16 of course, all religious groups have the right (enshrined in art. 16 of the Constitution and in art. 9 of the ECHR) to freely disseminate their doctrines, with respect to public order and to the rights and freedoms of others. But the inclusion of confessional religious instruction in public schools, and the corresponding assignment of public funds thereto, is an expression of state cooperation with religion that has its roots in art. 27(3) of the Spanish Constitution and not only in art. 16(3).

The following pages describe in more detail the system of religious instructions in schools, which has been recently modified.17 But first, two important points should be clarified: First, the religious denominations may provide religious instruction in public schools only upon the request of the students' parents. Nobody shall be obliged to receive confessional religious instruction against the wishes of his/her parents or legal representatives. Second, not all religious denominations are entitled to provide religious instruction in public schools, but only those with which the state has concluded a cooperation agreement (i.e. the Catholic Church, and the communities integrated into the Evangelical, Jewish and Islamic federations).

\section{B. SCHOOL AND RELIGION}

\section{Public and Private Schools}

Pre-university schools in Spain may be public or private. The former are owned and managed by the state or the autonomous communities, and may not have a specific religious or confessional orientation. The latter are owned by individuals or societies, and may be of religious orientation or of secular orientation (i.e. non-confessional schools). In both cases, they are entitled to possess their own fundamental principles (the so-called ideario) defining their aims and functional characteristics. The immense majority of private schools in Spain are of Catholic orientation and provide religious teaching along the entire educational curriculum.

16. See below, para. II.4.

17. On the legal panorama of school and religion in Spain, see generally (from different perspectives and with diverse assessment of the system): P. Lorenzo Vázquez, Libertad. religiosa y enseñanza en la Constitución (Madrid, 2001); J. Mantecón, "L'enseignement de la religion dans l'école publique espagnole," Revue Générale de Droit 30 (1999/2000): 277; J.M. Martí, "Factor religioso y enseñanza en España," Anuario de Derecho Eclesiástico del Estado 16 (2000): 399; L.M. Cubillas Recio, Enseñanza confesional y cultura religiosa (Valladolid, 1997); A. Martinez Blanco, La enseñanza de la religión en los centros docentes (Murcia, 1994). 
Nearly one-third of pre-University Spanish students are in private schools (32.6 percent in the academic year 2003-2004).18 Secular or religious, private schools may be strongly subsidized by public funds when they comply with certain requirements concerning their functioning and the power of control granted to the public authorities and to the students' parents (school council).

The main statutes governing the legal status of schools and education are the following: Organic Law on the Right to Education (1985), Organic Law of General Order of the Educational System (1990), and Organic Law on the Quality of Education (2002), which modified significant parts of the other two statutes and, as we shall see later, modified substantially the system of religious instruction in public schools. ${ }^{19}$

\section{Catholic Religious Education in Schools}

As indicated before, shortly after the 1978 Constitution was enacted, the Spanish state signed four cooperation agreements-on diverse matters-with the holy see. One of them, the Agreement on Education and Cultural Matters, ${ }^{20}$ regulated the teaching of Catholic religion in schools. This regulation was the result of:

a. art. $27(3)$ of the Constitution-parents' right over their children's religious education;

b. art. 16(3) of the Constitution-the state is obliged to cooperate with religious denominations according to the beliefs of Spanish society;

c. the deeply rooted Spanish tradition of providing-and financingCatholic religious instruction in public schools.

The 1979 Agreement on Education and Cultural Matters covered different matters that went beyond the subject of this essay. With regard to this issue, its main provisions were the following: 21

a. Catholic religious instruction has to be included in the school curricula of all pre-university educational levels.22 The same rule applies to the university schools for teachers' training. Catholic instruction shall not be mandatory for students, but all public schools are obliged to offer it to the students as an option.

b. Notwithstanding its voluntary character for students, the teaching of

18. The statistical data can be seen in the web pages of the Ministry of Education: http://wwwn.mec.es/mecd/jsp/plantilla.jsp?id=31\&area=estadisticas.

19. Ley Orgánica 8/1985, reguladora del Derecho a la Educación, 3 July 1985; Ley Orgánica 1/1990, de Ordenación General del Sistema Educativo, 3 October 1990; Ley Orgánica 10/2002, de Calidad de la Educación, 23 December 2002.

20. The text of this agreement (in Spanish version) can be found in: http://www.mju.es/asuntos_religiosos/ar_n04_e.htm.

21. See esp. arts. I-VI of the Agreement on Education and Cultural Matters.

22. The terminology used to name these educational levels has been changing since 1979 , but they cover from primary through secondary education. The current names are: primary education, secondary education, and Baccalaureate (in Spanish: educación primaria, educación secundaria, bachillerato). 
Catholic religion in schools has to be included-in its different levels-as a course in conditions equal to the rest of the fundamental courses of the school curricula. This provision includes a proportionate assignment of credits to the subject of Catholic religion.23 On the other hand, the school authorities must ensure that students' choice in favor of Catholic instruction does not produce negative or discriminatory effects with regard to their school activity.

c. Catholic religious teachers are appointed by the ecclesiastical hierarchy, which is also the only competent authority to define the contents of religious instruction and to approve the relevant textbooks.

The basic legal status of the teachers of "Catholic Religion and Morals" was regulated in 1982 by an order of the Ministry of Education.24 Teachers are appointed by the Catholic bishop corresponding to the diocese where the school is located. Appointments are for a one-year term, and are automatically renovated every year unless the relevant bishop decides to remove a teacher that is no longer considered appropriate for that function. Teachers of Catholic religion are not required to serve as full-time teachers (but they may do so), and can teach other subjects different from religion at the same school, provided that they possess the necessary academic requirements. To be appointed a teacher of Catholic religion it is necessary to have obtained a declaración eclesiástica de idoneidad, i.e. a certification of competence, granted by the ecclesiastical hierarchy, which requires a minimum of theological studies. ${ }^{25}$ In addition to clergymen, there are many lay peoplemen and women-appointed by the Spanish bishops to teach religion in schools.

Although teachers of Catholic religion are selected by the ecclesiastical hierarchy, they are hired and paid by the state. The teachers that are not civil servants with tenure are employed, under a regime of labor contract, for the term of one academic year, full-time or part-time; they receive a salary equal to that of interim teachers of other subjects, according to the number of teaching hours per week. ${ }^{26}$ Teachers who only teach religion are not eligible

23. Regarding teacher training of Catholicism in a university, the Constitutional Court has ruled that the university school must offer that subject as an option to the students, for it is obligated to do so by an international treaty (the agreement with the holy see); and that the school must also allocate a number of credits which is proportionate to the other fundamental subjects of the curriculum. See, respectively, STC 187/1991, 3 October 1991; and STC 155/1987, 29 September 1997.

24. Order of 11 October 1982. On the legal status of religion teachers, see J. Otaduy, "Estatuto de los profesores de religión. La jurisprudencia del Tribunal Supremo," in Actualidad canónica a los veinte años del Código de Derecho Canónico y a los veinticinco de la Constitución (forthcoming); M. Rodríguez Blanco, "El régimen jurídico de los profesores de religión en centros docentes públicos," Il diritto ecclesiastico 112 (2001): 482.

25. See the specific requirements in the following Internet address: http://www.conferenciaepiscopal.es/ensenanza/dei.htm.

26. See art. 93 of the Ley $50 / 1998$, de Medidas Fiscales, Administrativas y de Orden Social, 30 December 1998, which modified the second additional provision of the Ley 


\section{for the position of school director. ${ }^{27}$}

The social demand of Catholic instruction in school is high, although numbers decrease as the students' ages increase; the percentage of students that choose classes of Catholic instruction is much higher in elementary and primary education than in secondary education, especially in public schools. In the last years, if we combine the data from the different educative levels and from all educational centers-public, private Catholic, and private secularthe percentage of Spanish pre-university students taking voluntarily the subject "Catholic Religion and Morals" is between 75 and 80 percent. ${ }^{28}$

Along the years, there have been two main conflictive aspects arising from the system of Catholic instruction in Spanish schools, which have caused some political tension between governments and the ecclesiastical hierarchy.

The first aspect refers to the subjects offered as an alternative to the students that did not opt for "Catholic Religion and Morals." The Spanish Ministers of Education have put into practice different plans, almost all of them with a common characteristic: the altemative subjects were not demanding, and did not have actual academic value. For that reason, the Spanish Bishops Conference has often expressed its opposition to those plans; in the bishops' view, the system discouraged students from choosing Catholic instruction in school-compared with the alternative courses, it implied an extra academic effort on the part of the students. In addition, the bishops pointed out that offering a trivial alternative subject without real academic weight contributed to devaluate in practice the teaching of religion and was a violation of the 1979 Agreement on Education and Cultural Matters with the Holy See, whose articles II and IV explicitly require that Catholic religious instruction be offered in conditions equal to the rest of the fundamental disciplines. The 2002 Law on the Quality of Education endeavored to solve this problem, as will be explained later.

The second conflictive point relates to the fact that the contractual relationship of religion teachers is with the state-which hires and pays them-but its appointment, and removal, is in the hands of the Catholic hierarchy. As indicated before, the bishop of the diocese where the school is located must confirm the appointment of religion teachers (at least implicitly) every year and, consequently, may remove them at his discretion when he ceases to consider a teacher appropriate to fulfil his/her educative function. Some conflicts have arisen-with remarkable impact on mass media-when some religion teachers have been removed not for lack of doctrinal competence or for theological deviations, but rather for behaviors that are

Orgánica 1/1990, de Ordenación General del Sistema Educativo, 3 October 1990. See also the following orders of the Ministry of Education: Order of 26 September 1979, Order of 26 November 1984, and Order of 9 April 1999.

27. The Constitutional Court has held as constitutional the two provisions relating, respectively, to the stipend of religion teachers and to their ineligibility as school director. See ATC 1155/1987, 26 October 1987, and STC 47/1990, 20 March 1990.

28. Reliable and detailed statistics can be found in the following Internet address: http://www.conferenciaepiscopal.es/ensenanza/. 
deemed contrary to Catholic morals, e.g. for celebrating civil marriage, obtaining a civil divorce from a canonical marriage, or getting pregnant without being married.

Part of the problem derives from the hybrid character of the legal status of religion teachers. On the one hand, they are appointed by the ecclesiastical hierarchy, which seems logical from the point of view of the churches' right to their own autonomy, ${ }^{29}$ taking into account that only the ecclesiastical authorities may decide who is competent to teach the Catholic doctrines. But, on the other hand, as the contractual labor relationship of religion teachers is with the state, they may be entitled to the same rights, and contractual stability, that the rest of state employees enjoy. This is probably one of the aspects of the system of religious instruction that deserves a more careful revision. In any event, the Constitutional Court has recently granted certiorari (i.e. declared admissible) some "questions of unconstitutionality" posed by a Spanish court with regard to this aspect of the agreements with the holy see.30

\section{The Teaching of Religious Doctrines Other than Catholic}

While the 1979 Agreement on Education with the holy see provided for Catholic religious instruction in public schools, no legislative provision was made for the confessional teaching of other religious doctrines in the years that immediately followed the Constitution. The natural interpretation of the constitutional principle of equality, however, impelled an extension of the system to other churches or religious communities.

Some religious denominations, therefore, initiated immediate negotiations with the government in order to have their doctrines offered as an optional subject in public schools. The Mormon Church was the first to obtain such approval. Nevertheless, a general law of reform of the Spanish educational system, in 1990, provided that the teaching of confessional religious instruction had to be regulated by cooperation agreements between the state

29. See the following European Court of Human Rights' cases (related to very different matters, but all of them coincident in remarking that the state may not interfere with the right of religious denominations to their own autonomy and self-government): Serif $v$. Greece, 14 December 1999; Hasan and Chaush v. Bulgaria, 26 October 2000; Metropolitan Church of Bessarabia v. Moldova, 13 December 2001; Agga v. Greece, 17 October 2002.

30. Cuestión de inconstitucionalidad 4831/2002, declared admissible on 1 October 2002; cuestión de inconstitucionalidad 4126/2003, declared admissible on 15 July 2003; cuestión de inconstitucionalidad 5162/2003, declared admissible on 30 September 2003; cuestiones de inconstitucionalidad 785/2004 and 786/2004, declared admissible on 9 March 2004. All questions of unconstitutionality come from the same court: the Superior Court of Justice of Canary Islands. A "question of unconstitutionality" is a request by which any Spanish court may ask the Constitutional Court to pronounce on the constitutionality of a legal provision; this is normally done when a court considers a legal provision contrary to the Constitution, for in the Spanish legal system only the Constitutional Court is entitled to declare a legal provision unconstitutional. The problems derived from the legal status of religion teachers in Spain has been recently studies by J. Ferreiro, Profesores de religión de la enseñanza pública y Constitución española (Barcelona, 2004). 
and religious denominations, ${ }^{31}$ which in fact meant to restrict the offer of religious instruction in public centers to those churches that had concluded an agreement with the state.32 At that time, only the Catholic Church had that sort of cooperation agreement; therefore, the practical consequence was that all religious teaching other than Catholic was excluded from the schools' curricula.

The situation changed in November 1992, when the Spanish Parliament approved the three cooperation agreements with the Evangelical, Jewish, and Islamic federations. These agreements contained a specific provision with regard to religious education (art. 10). The teaching of Evangelical, Jewish, or Islamic religion is guaranteed, upon request of the students or their parents, in public schools or in private schools supported with public funds. Contrary to what occurred with the teaching of Catholic religion, schools are not generally obliged to offer the choice of Evangelical, Jewish, or Islamic religion unless there is an explicit application by some students or their parents-such an obligation would make no sense, for the number of the faithful of those religions would not justify it.

Regarding non-Catholic religious instruction, the teachers, the content, and the textbooks for this religious education shall be provided by the respective federations. No provision for state financing of non-Catholic religious instruction was made in the agreements of 1992 , nor in the royal decree that regulated religious education in more detail. ${ }^{33}$ However, in 1996, the state concluded a specific agreement with the Evangelical and Islamic federations, ${ }^{34}$ by virtue of which the state will pay the religion teachers, in conditions similar to the teachers of Catholic religion, as long as they teach to groups of at least ten students. The Jewish communities did not express a specific interest in joining that system in 1996 (probably because they though they could not reach the minimum number of students in a school); but, in the last two years, they have requested that the government integrate them in the same system.

By and large, it is possible to affirm that the current solution has been satisfactory to the largest part of non-Catholic religious denominations in Spain. The main problems relate to the religious denominations that are not integrated in any of the three federations that signed the agreements of 1992 with the state. This fact has produced some paradox-for instance, the Mormon Church which does not belong to the Evangelical federation and whose doctrine had been the first non-Catholic religious doctrine included in the curricula of public schools, is no longer taught in Spanish public schools

31. In particular, the second additional provision of the 1990 Organic Law of General Order of the Educational System.

32. The same rule is contained in the second additional provision of the 2002 Organic Law on the Quality of Education.

33. Royal Decree 2438/1994, 16 December 1994.

34. These two agreements were approved by the Council of Ministers on 1 March 1996.

There is no similar agreement with the Jewish federation, probably because it preferred not to receive funding from the state with regard to religious education. 
(since 1990). Apparently there are some other problems with regard to the appointment of teachers of Muslim religion, due to the difficulties of Islamic communities to agree on the appropriate persons. 35

\section{Regulation of Religious Instruction in the Recent Law on the Quality of Education}

In December 2002, the previous government enacted a statute allegedly aimed at correcting some of the functional deficiencies of the Spanish educational system in the last two decades; its name - Law on the Quality of Education 36 - is very significant in this regard. This statute adopted a new position in relation to the teaching of religion in school. ${ }^{37}$ Its intention was to reconcile the provisions contained in the state agreements with religious denominations (the 1979 Agreement with the Catholic Church and the 1992 agreements with the major religious minorities) and the recommendations of the Parliamentary Assembly of the Council of Europe, which has repeatedly encouraged the inclusion of a comparative teaching of religion in school as a way to foster tolerance. 38

According to the new law, all students in primary and secondary education must take courses in religion. The study of religion, therefore, will be mandatory in certain levels of education.

Not all courses on religion, however, are equal. Although the subject is always called "Society, Culture and Religion," the students can choose between confessional courses and non-confessional courses. ${ }^{39}$ The former shall

35. See recently, J. Mantecon, "Islam in Spain," in R. Aluffi and G. Zincone, eds., The Legal Treatment of Islamic Minorities in Europe (Leuven, 2004), 227-29.

36. Cited in n. 19.

37. See M.E. Olmos Ortega, “Sociedad, Cultura y Religión: nueva área de conocimiento propuesta por la Ley de Calidad de la Educación," Revista General de Derecho Canónico y Derecho Eclesiástico del Estado 1. (2003); and M.E. Olmos Ortega, "Sociedad, Cultura y Religión: asignatura de doble configuración," Revista General de Derecho Canónico y Derecho Eclesiástico del Estado 3 (2003); available online at www.iustel.com.

38. Thus, Recommendation 1396 (1999), on Religion and Democracy, recommended: "ii. to promote education about religions and, in particular, to: $[\ldots]$ b. promote the teaching in schools of the comparative history of different religions, stressing their origins, the similarities in some of their values and the diversity of their customs, traditions, festivals, and so on." And Recommendation 1202 (1993), on Religious Tolerance in a Democratic Society, recommended: "iii. to ensure that studies of religions and ethics are part of the general school curriculum, and to work towards a differentiated and careful depiction of religions in school books (including history books) and in classroom teaching with a view to achieving a better and deeper understanding of the various religions."

39. The second additional disposition of the Organic Law on the Quality of Education provides (author's translation):

a. The area or subject Society, Culture and Religion shall comprise two possible options. One is of confessional character, in accordance with the religious confession chosen by the parents or, when appropriate, by the students among those religious confessions that have signed cooperation with agreements the state. The other is of 
be provided according to the rules of the 1979 Agreement with the Catholic Church and the 1992 agreements with the Evangelical, Jewish, and Islamic federations; i.e., the relevant religious authorities determine the content, the teachers, and the textbooks of the courses, for these are aimed at the instruction of students in a particular faith. The latter shall be designed by the state, with the aim of providing a pluralistic or comparative knowledge of religion; this type of course is not intended for indoctrination in a particular religion but rather for the study of religion as a cultural element in society 40 No exemption from religion courses is foreseen for students; they must necessarily take either confessional or non-confessional courses, at their own free choice.

Although, as indicated before, the 2002 Law on the Quality of Education endeavored to reconcile the state cooperation with religious denominations and the recommendations of the Council of Europe, the party now in government (since March 2004-the Socialist Party) declared incessantly during the electoral campaign, its intention to derogate large parts of this law, with specific references to the teaching of religion. At the same time, shortly after his appointment, the current minister of justice declared that he wished to modify the 1979 Agreement on Education and Cultural Matters with the holy see.

Consequently, the situation is uncertain at this moment. The tension between the socialist government and the Catholic bishops has continuously increased since March 2004, largely, but not exclusively, due to the issue of religious education in public schools. However, no attempt to initiate negotiations for the revision of the 1979 agreements has been made at the moment, and the government has no longer reiterated its intention to revise the Concordat with the holy see.

non-confessional character. The schools are obliged to offer the two options and the students must choose one of them.

b. Confessional teaching of religion shall be carried out according to the provisions of the Agreement on Education and Cultural Matters between the holy see and the Spanish state, and, when appropriate, to the provisions of other agreements that have been or may in the future be signed with other religious denominations.

c. The government shall determine the common teachings corresponding to the nonconfessional option. The relevant religious authorities shall be competent to determine the curriculum of the confessional option. The decisions on textbooks and didactic materials, and, when appropriate, the supervision and approval of the same, correspond to the relevant religious authorities, in accordance with the provisions of the agreements signed with the Spanish state.

40. The curricula of the non-confessional option of the courses on Society, Culture and Religion have been determined by the state in the following royal decrees: Real Decreto 829/2003, 27 June 2003 (elementary education), Real Decreto 830/2003, 27 June 2003 (primary education); and Real Decreto 831/2003, 27 June 2003 (secondary education); Real Decreto 832/2003, 27 June 2003 (baccalaureate). 


\section{Other Issues Concerning School and Religion}

There are no mandatory religious ceremonies in public schools, neither Catholic nor of any other religion. In addition to the implications related to the constitutional principle of state neutrality towards religion, such ceremonies would be contrary to the fundamental right to religious freedom as recognized in art. 16 of the Constitution and art. 2 of the Organic Law on Religious Freedom. 41

As a matter of fact, normally there are not any religious ceremonies at all in public schools. According to the Spanish law-an order of the Presidency of Government, in $1980^{42}$ - there must be specific premises in public schools available to the students for religious ceremonies and religious assistance-of course, attendance has to be voluntary. The detailed regulation of this religious assistance, additional to religion classes, is left to future agreements between the state and the churches (with a specific mention of the Catholic Church, which was the real issue in those times, for there were chapels and chaplains in most public schools). ${ }^{43}$ However, contrary to what has occurred in the field of religious assistance to hospitals or penitentiaries, no agreement with the Catholic Church or with any other religious community has been concluded.

The provisions of the 1980 order have not been made real: apparently, in the subsequent years, the newly created public schools did not reserve any space for worship places, although the old ones have often been preserved. Normally, no religious ceremonies are performed in public schools. The most significant exception are funerals, when a student or teacher dies during the academic year; in those cases, the families of the deceased demand a memorial service, usually Catholic, which is seen as normal by the school

41. Art. 2(1)b of the 1980 Organic Law guarantees the right of every person "not to be obliged to practice acts of worship or to receive religious assistance contrary to his or her personal beliefs."

42. Orden of 4 August 1980, por la que se regula la asistencia religiosa y los actos de culto en los Centros escolares.

43. These were the provisions of the 1980 order of the Presidency of Government (following a proposal of the Ministries of Justice and of Education):

a. In all public schools of elementary and secondary education, Baccalaureate, and professional education, appropriate premises shall be made available, within the school area, for the development of activities of religious instruction and assistance directed to the students who wish to participate, including acts of worship.

b. The competent school authorities shall agree with the Catholic hierarchy, or, when appropriate, with the authorities of the legally registered churches or religious communities, the precise conditions under which those activities of religious instruction and assistance, complementary of the teaching of religion and morals, should be developed.

c. The existing chapels, oratories and other places permanently dedicated to Catholic worship in public schools shall remain dedicated to this function as well as to other activities of religious instruction and assistance; the relevant ecclesiastical hierarchy shall be competent to decide on issues concerning the religious character of those chapels and places, without prejudice to their possible use for other school activities. 
community.

In private confessional schools, there are religious ceremonies and places of worship. Most of them, as indicated before-and indeed the most prestigious as educational centers-are of Catholic orientation. Though the situation may vary in each Catholic center, school authorities tend not to oblige students to participate in religious ceremonies, especially when they adhere to other religions. However, most parents take their children to Catholic schools for a number of reasons that include religious instruction; consequently, most often the students' parents wish their children to participate in the religious acts organized by the school.

On a different front, there are no big issues with regard to students wearing religious garments in public schools or the use of religious symbols on public school premises. There is no specific legislation on those subjects, and normally the school council is competent to adopt the relevant decisions. Therefore, the situation may be considerably different depending on the schools.

With respect to students wearing religious garments, it is possible to affirm, by and large, that the attitude of Spanish society tends to be tolerant with the free expression of religious beliefs. A proof of this is the fact that no problems seem to have arisen in public schools in the autonomous Spanish cities of Ceuta and Melilla (located on the African coast), notwithstanding the fact that the percentage of Islamic students is approximately 50 percent. The only reported case relates to a Muslim female student, not come of age, in the Region of Madrid. The conflict arose, in February 2002, in the city of San Lorenzo de El Escorial, when she wanted to attend school wearing her Islamic headscarf. The student had been initially registered in a private school financed by public funds (centro privado concertado), but she never attended classes there because the director forbade her to wear her Islamic headscarf. As the student was absent from classes, the school reported to the Secretary of Education of the Autonomous Community of Madrid. A couple of days later, the Secretary of Education ordered that the student had to be admitted, without any condition concerning her headscarf, by a public school in the same city, against the contrary opinion of the director of that center, who was in favor of forcing the student to remove her veil. Subsequently, the school council passed a rule forbidding female students to attend physical education classes wearing headscarves, to avoid the risk that may be caused by headscarves during the practice of some sports (especially taking into account that women normally use pins to fix the veil).

A similar situation can be noted in relation to religious symbolism on public schools premises 44 - there has not been significant conflicts. As there is no specific legislation, the school council is competent to rule on the subject. Public schools do not have, and can not have, a confessional orientation, for

44. See, on this subject, S. Cañamares, "Las manifestaciones externas de religiosidad en el ordenamiento jurídico español: el empleo de simbología religiosa," in the collective volume, El ejercicio de la libertad religiosa en España: cuestiones disputadas (Madrid, 2003), 177. 
this would be considered contrary to the neutrality of the Spanish state. Most schools do not have religious signs in classrooms, although some schools may have a crucifix on the wall. To this author's knowledge, there have not been many contrary reactions against religious symbols on the part of the students or their parents. The author knows of only two reported cases of conflict in recent years: one in Barcelona, the other in Madrid.

The former arose in February 2002, when the parents of some Muslim students requested from school authorities the removal of the crosses from the classrooms of their children's courses; 45 they alleged that those religious symbols could influence their children's religious beliefs. The school was not public-it was a private school financed by public funds (centro privado concertado), run by the religious Catholic order of Gabrielists, within the province of Barcelona. The conflict was solved in a pragmatic way: the Secretary of Education of the Catalonian government (Generalitat) ordered that the students be transferred to a public school within the same town, where no religious symbols existed in the classrooms.

The other conflict took place in a public school in Madrid (Colegio San Benito) in 1998, when the school parents' association, moved by some parents of atheist convictions, requested that all religious symbols, mainly crosses, be removed from the school premises. ${ }^{46}$ After the school council refused to do so, the parents' association asked for the intervention of the Ministry of Education, which - through its General Directorate on Educational Centresrejected the notion that the students' parents were entitled to request the removal of the crosses and pointed out that the school council was the only competent authority to decide on the issue. Following a legal suit of the parents' association, the Superior Court of Justice of Madrid delivered its decision in October 2002; 47 the court considered that it could not pronounce any judgment on the merits (i.e. whether state neutrality necessarily required that crucifixes be taken away from classrooms), but ruled that the Ministry of Education was obliged to adopt a decision on the issue that could, if appropriate, be challenged before the courts. The story ended when the school council, to avoid further conflicts and tension in the school, voluntarily decided to remove religious symbols from classrooms, with the exception of the classroom where religious instruction was provided.

45. See the Spanish newspapers La Vanguardia, 22 February 2002, and La Razón, 19 February 2002.

46. For the details of this case, in the context of a discussion of the use of religious symbolism in public spaces in Europe, see G. Moreno Botella, "Libertad religiosa y neutralidad escolar. A propósito del crucifijo y de otros símbolos de carácter confesional," Revista Española de Derecho Canónico 58 (2001): 173, 207.

47. Sentencia del Tribunal Superior de Justicia de Madrid núm. 1105/2002 (Sala de lo Contencioso-Administrativo, Sección 9ª), 15 October 2002. 


\section{Воок REVIEWS}

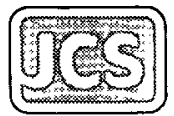


HeinOnline -- 47 J. Church \& St. 1522005 